\title{
New IPCC report set to confirm earlier warming conclusions
}

London. The principal United Nations advisory committee on the scientific nature and impact of climate change is expected to confirm its initial assessment, first published five years ago, that human activity is playing a significant role in global warming.

Despite continued scepticism from some scientists, the new report, due to be published later this year by the Intergovernmental Panel on Climate Change (IPCC), is expected to repeat earlier warnings made in its first report, published in 1990.

A draft version of the "second assessment synthesis report", which has been circulating for comment in parts of the scientific community, says that observed increases in the global mean temperature of between 0.3 and $0.6{ }^{\circ} \mathrm{C}$ "is unlikely to be entirely due to natural causes".

Comparison of observed temperature change with model simulations, says the draft, means that "the best evidence to date" suggests that "a pattern of climatic response to human activities is identifiable in the climate record".

Much of the new certainty comes from the increasing sophistication of climate models over the past few years, and in particular from results of running models simulating the combined effects of greenhouse gases (which tend to increase surface temperature) and shorter-term effects of aerosols (which tend to reduce it).

The report admits that the observed warming of the globe has been smaller than that projected by models that include the impact of greenhouse gases alone. It also admits that there remains considerable "unexplained variation" between the detailed patterns of the warming observed and model projections.

Nevertheless, in an important conclusion - which reflects that reached by its Working Group 1 and reported earlier this year - the draft report states that "agreement is generally better than those which include greenhouse gases alone".

IPCC officials are embarrassed that the draft of the second assessment report was 'leaked' through the Internet as part of its review process. They are quick to emphasize that the detailed conclusions may be modified in the final version of the report.

But scientists familiar with the debate that has been taking place on the content of the final report say that the broad thrust of such conclusions - in particular, that recent work with climate models has reinforced the conclusion that human activity is a major factor in global warming - is unlikely to be altered.

\section{BA puts government science move under the microscope}

Newcastle-upon-Tyne, UK. Basic science in Britain appears to have more supporters in industry than in government, according to the evidence of a former science adviser to the UK Department of Trade and Industry (DTI) during the first years of the administration of the Prime Minister, John Major.

Addressing a public forum during the annual meeting of the British Association for the Advancement of Science, Geoffrey Robinson, director of IBM's Hursley Laboratory, said that industry is keen to conserve Britain's reservoir of basic science.

Science, on the other hand, is important to government, as witnessed by the amount of money spent on research. But, he added that government has no "real feeling for basic science," as it is not a high-profile, mainstream political issue. Governments, he says, fund science because of its prior commitment to the public funding of research.

"Many scientific issues are central to government policy, but this does not include the broad span of science. Sitting round the cabinet table talking of science in the abstract is not a principle of central government."

Robinson was a key figure in drafting the DTI's contribution to the 1993 science white paper Realising Our Potential. He left the government in January 1994 when his post was abolished during a reorganization of the DTI following both the publication of the white paper and a separate series of decisions to cut back the DTI's funding for technology research programmes.

But he still defended the government's moves to bring science closer to industry including the recent controversial decision to move the Office of Science and Technology from the Cabinet Office into the DTI (see Nature 376, 103; 1995) - claiming that the move need not necessarily undermine basic science.

However, Robinson added: "I do think there is still only limited debate between industry and government on the importance of basic science.

"The notion that industry is competing with science is absurd," said Robinson. "Science and industry are pursuing two different but complementary agendas. A strong basic science is vital to industry."

Robinson said particle physics, which is relatively unknown to industry, ought to be held in high regard. "High-energy physics is a demanding and rigorous discipline which attracts many intelligent people," he said. "Industry needs first-class minds and particle physicists are first-class minds."

The forum was convened by Sir Martin Rees, Britain's astronomer royal and this year's president of the BA, to discuss the implications of the OST's transfer. The move, of which there was no prior warning, has cast a dark cloud over three years of relatively good relations between government and scientists.

Many critics have claimed that shifting the OST to the DTI threatens curiositydriven research, and that it has weakened the potential influence of both the government's new chief scientist, Robert May, who will now operate from within the DTI, and the highly regarded Ian Taylor, the new junior minister for science and technology.

Both May and Taylor were present at the Newcastle meeting and used the occasion to allay the concern of scientists. At the same time, however, both reiterated the government's belief that science must be better harnessed to the task of wealth creation.

Addressing a press conference, Taylor dismissed the government's critics as a small, if vocal, minority. "Most of the people I've talked to are positive about it. I've had a fistful of letters. They all realize that the future of basic science rests on a parallel development of that science in industry.'

May suggested the importance of the OST as a relatively free-standing body within the Cabinet Office had been exaggerated, and added he could make an equally good case for other arrangements. "The problem is not where to place the OST, but to better translate our world-class research into wealth creation," said May. "In that sense, the DTI is a sensible place to put it."

May pointed out that the United Kingdom, while leading many other countries in the production of scientists and engineers, lags behind in ensuring their adequate representation in the workforce.

But dissenting voices still abound. Sir Sam Edwards, professor of physics at the Cavendish Laboratory, University of Cambridge, questioned both whether basic research can be usefully directed to enhancing the quality of life, and the wisdom of forcing scientists and industry to interact, when countries such as Japan without such a tradition appear more successful at wealth creation than the United Kingdom.

"We are the envy of the world in terms of interaction of universities and industry," said Edwards, a one-time chairman of the former Science and Engineering Research Council. "Many graduates come from overseas. If we're so awful, why do they keep coming?"

Indeed, Edwards put forward the unfashionable hypothesis that the United Kingdom has too many scientists - rather than too few - and that this is the main reason that salaries for scientists are lower than in other comparable professions. "This is an immutable law of supply and demand," he said

Ehsan Masood 